\title{
PSYCHOLOGICAL CULTURE IN PHENOMENOLOGY OF PERSONALITY SELF-DEVELOPMENT
}

\section{Kuzikova S. B.}

\section{INTRODUCTION}

Expansion of the line of cultural-historical determination of personality development, which has been outlined by L. Vygotsky, allows understand more precisely the inner world of a modern man and raise the question about conditions and content of the formation of an individual picture of the world. This is especially relevant for modern youth, which, unfortunately, is, to some extent, passive in relation to own development and dependent on external motives, whereas modernity demands from it the initiative and responsibility - that is, the subjectivity of behavior and self-development. In our opinion this characteristic of youth can be explained by the following. Today the regulation of human life from the side of society has gone past. At the present stage of development of society young man has wide opportunities for self-expression, self-determination, self-realization of psychological and personal potential. However, most young people do not have the skills and techniques of reflection and self-regulation, that is, they do not know what to do with the freedom given for selfdetermination and self-realization and how to do it. Therefore, the presence of clear vital intentions and desires does not always lead to a purposeful activity towards their realization. The problem is complicated by the fact that there are young people who are not determined in their intentions, do not feel their autonomy, self-identity, and do not see the prospects of self-realization. This increases the significance of the study of the mechanisms and factors of the formation of the individual as a subject of self-development, which, in our opinion, correlates with its psychological culture ${ }^{1}$.

1 Кузікова С. Б. Психологічні основи становлення суб'єкта саморозвитку в юнацькому віці : монографія. Суми : Видавництво «МакДен, 2012. 410 с. 


\section{Understanding of the psychological culture as a person's ability to conscious self-development}

The development of applied psychological research of personal growth introduces new concepts into the categorical apparatus of science. To such concepts belongs psychological culture. The process of self-development of a person (values, norms and ways of organizing of behavior) and cultural-historical universals (O. G. Asmolov, G. V. Ivanchenko, I. F. Isaev, M. S. Kagan, E. S. Markaryan) is distinguished in the culture in philosophical studies. Human culture in general and psychological culture in particular is the result of a philosophical comprehension of reality, issued in the form of a semantic picture of the world.

Personal growth is a culture of a way of organizing psychological experience that arises as a result of educational, therapeutic or spiritual practice and holistically organizes the process of personality development, directing it into the future. During development, the subject makes fragments of reality a part of a personal system, developing certain strategies and tactics of their interpretation and technology of managing them. Similar strategies are made for the knowledge of their own states, actions, qualities and management of them. If this process occurs consciously and self-directed, the person can be considered the subject of self-development. According to our position, this testifies to the extent of the psychological culture of the individual.

In the process of theoretical study, we have identified the main psychological mechanisms of self-development as subject activity: interiorization, reflection, identification, exteriorization. Under "internalizations" it is accepted to understand the formation during the ontogenesis of the internal structures of the human psyche due to the assimilation of external structures of interpersonal relations. This formation mediates the entire process of age development and the formation of personality. In our opinion, this is also the formation of the self-concept and concept of life, a way of interaction with oneself and the outside world.

We tend to interpret the identification as the process of identifying the subject with another individual or a group on the basis of established emotional connection, inclusion in own inner world and acceptance own norms and values of the environment. Thus identification helps to find 
new values, meanings and forms of activity (M. Boryshevsky, G. Adams, G. Grotevan, E. Erickson, J. Marcia, etc.). However, Jung's opinion is valuable. He cautions against the notion that the person is expanding thanks only to the inflow from the outside. He says: "... When any great idea that comes from outside, takes possession of us, we must understand that this is only due to the fact that something is consistent with this idea and goes out to meet it" ${ }^{2}$.

Reflection is also one of the important mechanisms of selfdevelopment, since it involves self-knowledge by the subject of internal mental acts and states, the inner experience of man. Reflection, as a process of knowledge of personal psychic acts and states, allows us to distance ourselves from everyday life, to become "out of place" position (M. Bakhtin), to find vital senses, to form values. Reflection is connected with the comprehension of a person as a holistic person and awareness and assessment of actions based on the prediction of the corresponding reactions of another person. Due to its action it is possible to distinguish two main functions of self-consciousness (J. Brem, R. Viklund, S. Duval, L. Vygotsky). The first is the support of internal coherence and self-identity, so that an individual can build own behavior and attitude towards those around him. As a rule, it consists in ontogenesis, is realized in the society and is an indispensable attribute of a person's psychological life. And the second is knowledge of oneself, the search for the meaning of life, self-improvement. It can be seen as a means of personal and professional growth. Therefore, it must be secured and supported by a specially organized psychological influence, especially in adolescence and in the context of professional development of a future specialist.

Exteriorization is the later and most productive mechanism of selfdevelopment, because it is characterized by passing to the outside world the results of activity carried out in the internal plan of self-change, selftransformation and transformation of the external world. As A. Maslow noted, man is driven by a meta-values (according to E. Fromm, it is a realization of the desire to be), or it is managed by deficient needs (according to E. Fromm, it is a realization of the desire to give up). B. Ananiev includes a creative aspect to the notion of the subject of

2 Jung Carl. Synchronicity - An Acausal Connecting Principle. Vol. 8. of the Collected Works of C. G. Jung. 2010, 1972. 147 p. 
activity. Creation is often carried out when going beyond the specific situation and goes into creativity that promotes self-development of a person and getting her personality.

If the direction of self-development of individual in the integral context of life is determined by substantive components of selfconsciousness (personal meaning, values, goals, ideals, etc.), then its effectiveness depends on the peculiarities of the system of individual self-regulation (M. Boryshevsky, O. Konopkin, Y. Myslavsky, G. Nikiforov, O. Osnitsky and others). In this sense, self-regulation should be regarded as a functional means of the subject, which allows mobilizing personal psychological resources for realization of activity for the purpose of self-development. Consequently, we consider mechanism of reflexive self-regulation is a global, generalizing mechanism of self-development of a person. It consists in a holistic conscious self-organization and self-governing of personality by its functioning and development. We define reflexive self-regulation as a criterion for subjective self-development, also it can be considered as an indicator of the psychological culture of individual.

On the basis of an analytical review of psychological literature, using qualitative analysis, self-development of the individual in the life path can be presented in this way. Zone of actual development is the basic level, source, potential of self-development. In our opinion it is laid down in the prenatal period of ontogenesis and at each level of personality gradually becoming more complicated. In the prenatal period, the potential of self-development is created with the accumulation of experience of the child's activity and the experience of various emotions that are transmitted from the mother. After birth, the possibility of acquiring the experience of activity (motor, cognitive, etc.) and the experience of feelings, experiences, attitudes only increases.

Adult's zone of actual development (the potential of selfdevelopment) is characterized by psychological competence of a person and its psychological density: informational, sensory (attitude, experience - taking into account the sign of the emotional state), behavioral (communicative skills, self-regulation skills, skills in various spheres of life, including professional), etc. In our opinion personal competence can be identified with the psychological culture of man - its relation to the limitations and resources of personal development. 
However, the necessary condition for development (in accordance with the theory of L. Vygotsky) is the need of it. That is, the surrounding world (the zone of actual development) should be attractive, significant and necessarily more complex than the existing possibilities (zone of proximal development) of a person. This state of affairs actualizes the need for self-change, self-improvement, self-development in a person.

The psychological space of the zone of proximal development of the personality creates a range of its interests, hobbies, affairs, communication, information, emotional saturation, provides an acquaintance with world culture, with new life situations, new people, their knowledge, that is, the collision with the worlds of other people, their worldview, attitudes, visions. Contact with the enriched environment provides information for reflection, allows looking at the world through the prism of the perception of other people or other circumstances, facts, knowledge. That leads to decentralization, expansion of the individual living space, complication of inner psychological space, strengthening the sphere of self. In this case, assimilated characteristics of a personal potential are rising to a level higher. This is due to the mechanism of internalization - the appropriation of information of the outside world, which enriches the internal psychological structures, turning into personal information, personal knowledge.

However, person is not a vessel for the accumulation of knowledge, experiences, etc. Personal knowledge in general cannot be transferred from one person to another, they can only be worked out, found, understood. The information that a person receives from the outside must necessarily be subject to reflection. Only owing to reflection, thinking, the comparison of new information with existing experience, its identification with own views, beliefs, guidelines, new experience is assigned, becomes personal, passes to the category of "competence", actual development, enriching the inner world of a person, that is, going out for the limits of existing personal capabilities, manifested in personal growth.

From our point of view sensitivity to feedback is a significant factor and mechanism as a functional means of self-development of personality. Feedback can be considered as a new source of knowledge about yourself and the mechanism for adjusting of self-image. Personality can be considered only in the system of interpersonal relations, it is the product of these relations (B. Ananiev, G. Ball, 
S. Maksimenko, V. Myasishchev, V. Tatenko). Hence, for personal growth, one needs to see himself from the outside, knowledge of the way others sees and want to see you around, first of all, meaningful persons. Not necessarily that all received information will be accepted by a person, something does not coincide with ideas about itself and attitude to the world, personal meanings, values, goals. However, under favorable conditions - tolerance to novelty and adequate self-esteem, which involves autonomy, the development of the self-image and selfcriticism - taking into account the person's vision of others, of its own and the world as a whole will enrich the personality and will definitely contribute to personal self-development.

In our opinion, the two specified conditions for the appropriation (mastering) of new information - tolerance to novelty and adequacy of self-esteem - play an important role in a positive self-development of the individual. Obviously, you can face new information, worldview, values, and individual experiences of other people and reject them. This can happen for a variety of reasons. On the one hand, this is the pattern, the inflexibility of thinking, the rigidity of relationships, the low level of cognitive complexity of self-consciousness, communication with the world at a specific household level. On the other hand, the perception of new information impedes the person's confidence in own perfection and infallibility ("I am always right", "I am happy with what I am"). Such beliefs make a person unfavorable to feedback, the changing world and do not allow concentrate, look at oneself from the outside, through the eyes of other people. "Pride" was considered a sinful quality that does not contribute to spiritual perfection in Orthodox culture and its traditions. Indeed, a sense of self-sufficiency is a stoppage in development, psychological stagnation or homeostasis. Personality changes should occur, since the existence of the individual is a process and its stable condition is impossible. There is nothing terrible in feeling of own imperfection, defects, weakness. On the contrary, the feeling of own imperfection induces a person to self-development on condition of absence of a childhood helplessness complex (M. Seligman) and the preservation of search activity as a strategy of behavior (V. Rothenberg).

Let's focus on a fact that a person is able to realize his shortcomings, the imperfection of relationships with others only with the proper level of development of the self-concept. Observations and experimental data show that individuals with a well-crafted self-image, 
with high self-identity, autonomy, and sovereignty, have a high level of tolerance to novelty (information, the views of other people, ways of action, behavioral strategies), that is, they easily perceive the variability of life and change themselves, are self-developed.

An unproductive self-image, immature, diffuse identity leads to fear beyond own independence, complicates adaptation to changing social conditions of life, and impedes self-development. In this case, the person contacts the outside world with the help of defense mechanisms. An individual blocks self-changes, remains faithful to stereotypes, habitual assessments and forms of behavior fearing of losing I and dissolve. And he does not understand that life goes on, changes, acquires new forms, and therefore, he not only "remains the same", he lags behind, "becomes obsolete", does not correspond to the present life. Continuous self-development is not a luxury, but an indispensable condition for personal survival - a condition for maintaining a balance between life and person (two trains go in one direction, with one speed, with no backlog, or overtaking). Otherwise, a person has a feeling: I do not understand life, it becomes different, I am getting old, I do not get into a rut. The result is the loss of control over the course of life, the loss of self-esteem, and a person desperately clings to the old system, its behavior becomes protective. Often there is an immersion in the disease, various forms of escapism, neurosis if the mechanisms of psychological defense do not work.

Emphasize that a stable, perfected perception of the individual about himself is an important condition for personal self-development; it will allow to keep the core of the person with changes in its shells, peripheral dispositions. The phenomenon of learned helplessness ${ }^{3}$ complicates the self-development of the individual. Most frequently it is produced in childhood as a mode of behavior at multiple failures and lack of support in new, serious for person (especially children) situations. In this case, the feeling "I cannot" arises every time when colliding with a new one and it causes defense reaction (by type of various defense mechanisms) more likely than the reaction of search activity and self-development. In this case, we are talking about a strategy of human relations with undeveloped, new, more often with

${ }^{3}$ Seligman Martin E. P. Helplessness : On Depression, Development, and Death. San Francisco : W. H. Freeman, 1992. 250 p. 
difficult life circumstances: personal growth, self-development or avoidance, blocking of self-development and ultimately - personal crises, psychological and psycho-physiological (for example, psychosomatics) problems.

The ability of a person to perceive life problems and difficulties as an opportunity for self-development, self-improvement is a strategy of search activity and a characteristic of the subject of self-development (I understand the difficulties that have arisen and take responsibility for their solution. I believe in myself and my possibilities). From our point of view, the indicated human ability can equally be considered a characteristic of its psychological culture.

In many highly developed countries, social support systems for the marginalized population (who are mostly suffering from learned helplessness) allow a person to live comfortably at the expense of society, without even trying to contribute to its development. This situation has been considered in recent years in the United States, where a similar lifestyle is characteristic of $7.5-9 \%$ of the population and is a threat to national security. In our opinion, the formation of learned helplessness in Ukraine is in most cases due to the peculiarities of the mentality of the Slavic peoples - the desire to care for and control of their children, and also because of the historical factor - the long years regulated and secured life of previous generations on the minimum standard under the socialist system.

One of the alternative hypotheses of our study was the assumption of excessive, often unconscious using by youth (due to individual peculiarities of the formation of personality) of psychological mechanisms of Ego-protection, which blocks conscious and self-directed self-development. For diagnostics, we applied the personal questionnaire Pluchek Kellerman Konte - Life Style Index, LSI. The study involved students of the first-fourth courses of full-time humanities (146 people) and technical (132 persons) specialties. Totally 278 people were interviewed. The results of the study (Figure 1) showed that students of all courses are dominated by such mechanisms of psychological defense as regression and projection. The mixed type of MPD is characterized by severity of several Ego-protective mechanisms in one person. Regression of individuals who have high levels of Ego-protection, characterizes complacency to the influence of the environment, the presence of the need for stimulation, control, cheering. 


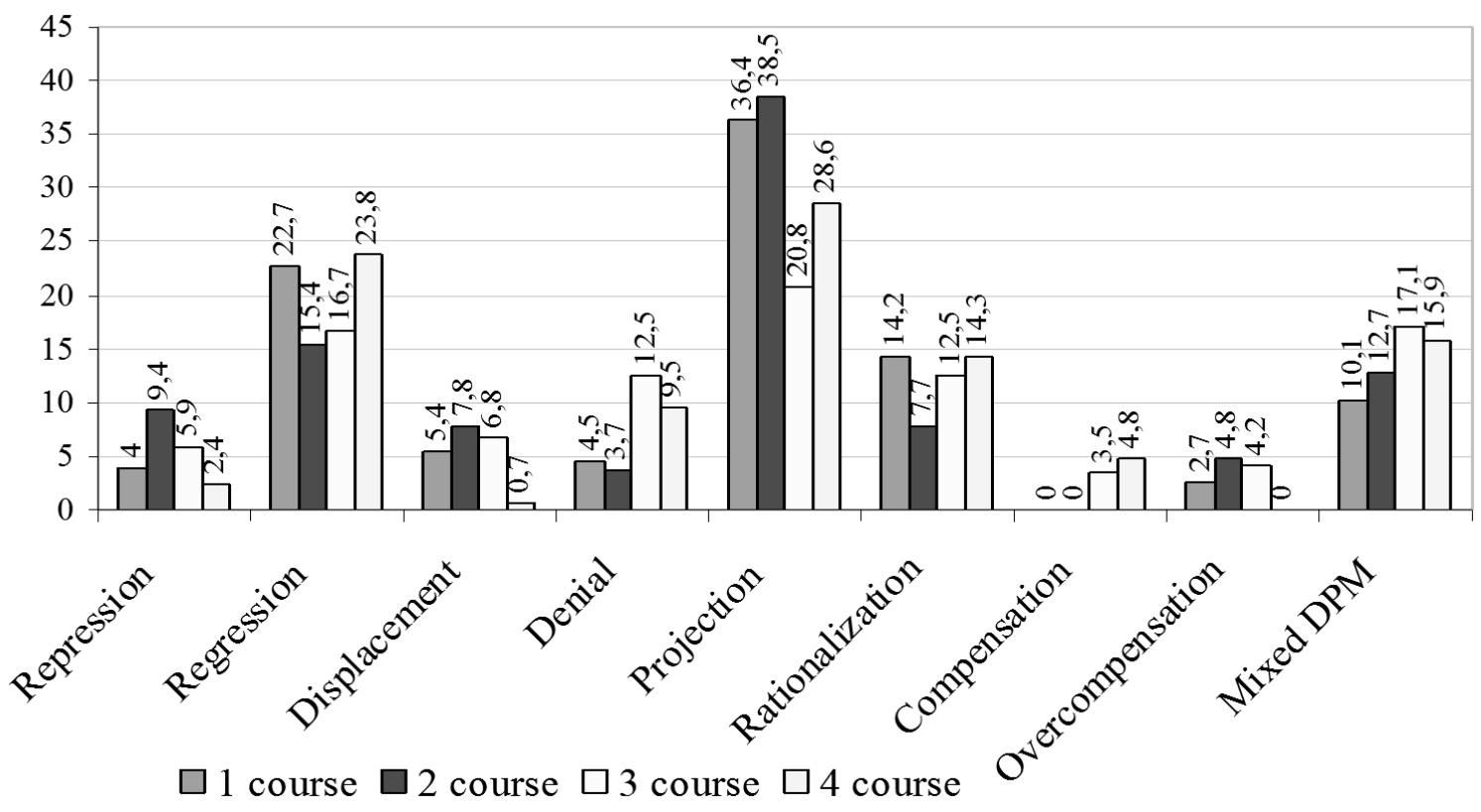

Fig. 1. Indicators of the severity of students' defense mechanisms

As a lifestyle they are characterized by slipping into a more primitive level of behavior or thinking under the pressure of "difficult" and irresistible (in their opinion) life situations, personal problems, emotional experiences. In the special literature, we find the following behavioral manifestations of regression: using of alcohol, game and computer dependence, talking to himself, reading bullying literature, trust to mystifiers, sucking fingers or biting nails. From our point of view, regression as Ego-protective mechanism manifests in infantile, irresponsible behavior of young men, the reduction of their life situations to the primitive-domestic level, the cynical attitude (devaluation) to the educational, cultural, and highly spiritual standards of society.

The essence of "regression" as the mechanism of Ego-protection can be transmitted as follows: if I do not possess the circumstances and myself in their context (I am not a subject of livelihoods and selfdevelopment), I simplify myself and life to a level on which I can keep self-esteem and self-integrity. The idea of "suppression", "avoiding of a spiritual growth" belongs to A. Angyal ${ }^{4}$. A. Maslow described the "complex of Jonah", which consists in the satisfaction of achieved, the refusal to realize self abilities in its entirety ("fear of its own greatness"

${ }^{4}$ Angyal A. Foundations for a science of personality. New York : Commonwealth Fund, 1941. 398 p. 
or "the desire to avoid calling of its talent") $)^{5}$. A. Maslow explained these manifestations, in particular, with the material prosperity of modern society. In our opinion, the explanation of the passivity and infantilism of modern youth lies in the system of their upbringing, in parents' desire to solve the mental (taking a decision) and material problems of children, to provide them all necessary (up to payment for studies at the university they chose).

Thus, young people receive certain life dividends (benefits) without any efforts. And therefore they do not feel themselves the cause, the initiators and the creators of these goods, which does not contribute to the formation of the subject of self-development.

Another student-dominated mechanism of psychological defense is projection. It is interpreted as a subconscious attribution of unacceptable for the individual (in terms of public morality or personal norms) his own qualities, feelings, desires to other persons, which frees the individual from their awareness, processing and responsibility ("everyone does it") and alleviates his self, subjectity. In our opinion, the revealed dominant mechanisms of defense testify to a certain degree of self weakness of youth, a low level of self-identity, autonomy, credibility, and hence the inability to be subjects (initiators and organizers) of their own life and self-development.

The low ability of a person to self-development (low level of autonomy, self-acceptance, self-identity, authenticity and tolerance to novelty) also complicates the personal relationship with the environment, reducing its social competence. In cases of misunderstanding of a person with the specified characteristics, it is difficult to comprehend information that does not correspond to his self image and his own worldview. Instead of accepting feedback, analyzing information and adjusting his attitude, behavior, person more often reacts to the situation in a sense of insult, guilt, irritation, or even hidden revenge. These feelings block personality self-development, fixing a person in the past.

We find the commandments, postulates, the culture of repentance and forgiveness, turning to Orthodox morality. Repent means to realize your imperfect, false actions that need to be changed, improved.

${ }^{5}$ Maslow A. Motivation and personality. New York : Harper \& Row; 2nd Edition, 1970. 369 p. 
Forgiveness of the "arbitrary" and "involuntary" actions of other people in relation to the individual frees from the past, elevates, cleanses, and makes him open to new relationships, which mean personal growth, spiritual, personal self-development.

Speaking about the psychological culture of the individual, let's dwell on one more essential moment. Obviously, in order to achieve the result of development, it is necessary to make some efforts. Even in arbitrary and internally managed processes of self-development there is a certain effort, not only the initial, "launching" process, but practically constantly present. Unfortunately, most modern youth do not want to "do their best", to work on themselves. That is, the problem lies not only in the absence of self-development motivation, but in the absence of habits and skills of self-organization, self-management, self-control, selfsufficiency. The formation of these self-processes is the most important task of modern practical psychology.

As you know, the category of effort is one of the key of M. Mamardashvili's theory. One of the main and tragic for the Russian mentality differences from the European one an outstanding philosopher saw in the absence of culture of effort that leads to spiritual devotion. At the same time, all European culture is built on life's efforts, on the assumption that a person only appears as an element of order, when he is in a state of maximum intensity of all forces. Unfortunately, modern mass culture, both European and Russian, clearly focuses on maximizing of satisfaction with minimizing of efforts. As D. Leontiev writes, one of the consequences of this is that quite a lot of people are using the opportunity to function at a lower, subordinate level, "because subordinate forms of existence are less energy-consuming, lighter, more attractive as the path of least resistance; human manifestations are the path of greatest resistance. To be a person is a work, making efforts" 6 . This problem was also raised by K. Obukhovsky ${ }^{7}$.

Thus, semantic gestalt (the individual vision of oneself and the world), the psychological culture of man are formed on the basis of personal meanings, values and determine the dynamics, direction and quality of its development.

6 Леонтьев Д.А. К дифференциальной антропологии. Наука и будущеее : идеи, которые изменят мир : Материалы междунар. конф. Москва, 2004. с. 107.

Obuchowski K. Człowiek intencjonalny, czyli o tym jak być sobą. Dom Wydawniczy REMIS, 2000. 257 s. 


\section{Continuous personal and professional self-development as an indicator of professional culture of personality}

The study of professional self-development of a personality in domestic psychology is based on general psychological statements about the nature and development of the individual as a subject of livelihoods (K. Abulkhanova-Slavska, G. Ball, M. Boryshevsky, A. Brushlinsky, G. Kostyuk, S. Maksimenko, S. Rubinstein, V. Tatenko); concepts of activity mediation of personal development (V. Davydov, S. Maksimenko, A. Petrovsky); scientific representations about the personality of a professional and pattern of his becoming (V. Bodrov, E. Klimov, G. Lozhkin, A. Markov, etc.). According to most modern domestic scientists, the formation of a professional is possible only as a result of the unity of professional and personal development. At the same time, tracing the peculiarities of the phenomenology of selfdevelopment of the individual as a subject of activity, the researchers emphasize the importance of professional activity which is optimal factor for creative self-development (K. Abulkhanova-Slavskaya, O. Bodalev).

Acmeological study of a person during life shows that the formation and manifestation of the qualities of an active subject of activity continue until this activity continues. Genuine deep and wide professionalism (this is evidenced by the experience of many outstanding people) cannot be acquired by a person only as a result of occupation by the activity which he devoted himself to, especially if this activity is complex in character. High professionalism is impossible without the development of special abilities, which in their content and form should be close to the requirements of specific activities, and without the corresponding requirements of knowledge and skills. However, the most important condition for the achievement of such professionalism is necessarily the powerful development of a person's general abilities, psychological culture, spirituality and the transformation of universal values into its own values, which means the moral upbringing of the individual. This is due to the fact that the personal space is wider than the professional; it underlies professional. Consequently, the criterion of the success professional activity, professional competence of a person and an indicator of its professional culture can be considered a continuous conscious and self-directed personal development. It is even more important to cause among young 
people a constant personal and professional demand for selfdevelopment in the context of professional training as a guarantee of professionalism for future professional activities.

Education is essential to the development of the intellectual and cultural potential of society. However, progress in all spheres of public life is so rapid that any specialist will be able to work efficiently and be competitive on the basis of education only.

Today, the concept of "competence of a specialist" is defined as a complex set of characteristics, which includes, in addition to cognitive and operational-technological components, motivational, ethical, social and behavioral, as well as knowledge, skills, system of value orientations as the results of learning. In this case, competence is not confined to competency. It should be emphasized that knowledge, skills and experience determine the competence of the person, and the ability to mobilize them in a specific socio-professional situation (selforganization, self-management) and determine the competence of an educated and professionally successful person.

For a person, a profession is a source of existence and a means of personal self-realization. Describing the types of professional competence, A. Markova reveals individual competence, emphasizing such a side of labor as a holistic professional self-development. Meaningful characteristics of professional self-development are: professional self-awareness, self acceptance as a professional; constant self-determination; self-development of professional abilities, internality, self-design, construction of own strategy of professional growth, construction and realization of own professional life, etc. (on the other poles - individual incompetence - professional self-development is characterized by opposite signs). If we summarize all these characteristics, then, first of all, we will receive motivational-volitional components of self-awareness, self-assessment, value orientation and self-esteem of the individual.

A. Markova emphasizes the uneven stages and levels of professional development of the individual, denoting it as an individual trajectory of professional growth ${ }^{8}$. The author considers the possible stages and variants of the dynamics of the balance among social and professional on the example of a personal self-development. We used

\footnotetext{
${ }^{8}$ Маркова А.К. Психология профессионализма. Москва, 1996. 308 с.
} 
the above-mentioned terms in developing a model (conceptual scheme) of professional self-development of a person (see Fig. 2). As a rule, the establishment of the level achieved by the individual as a subject of activity, and its opportunities are traditionally evaluated by the results of professional activity, in accordance with the mental properties of the professional requirements of activity.

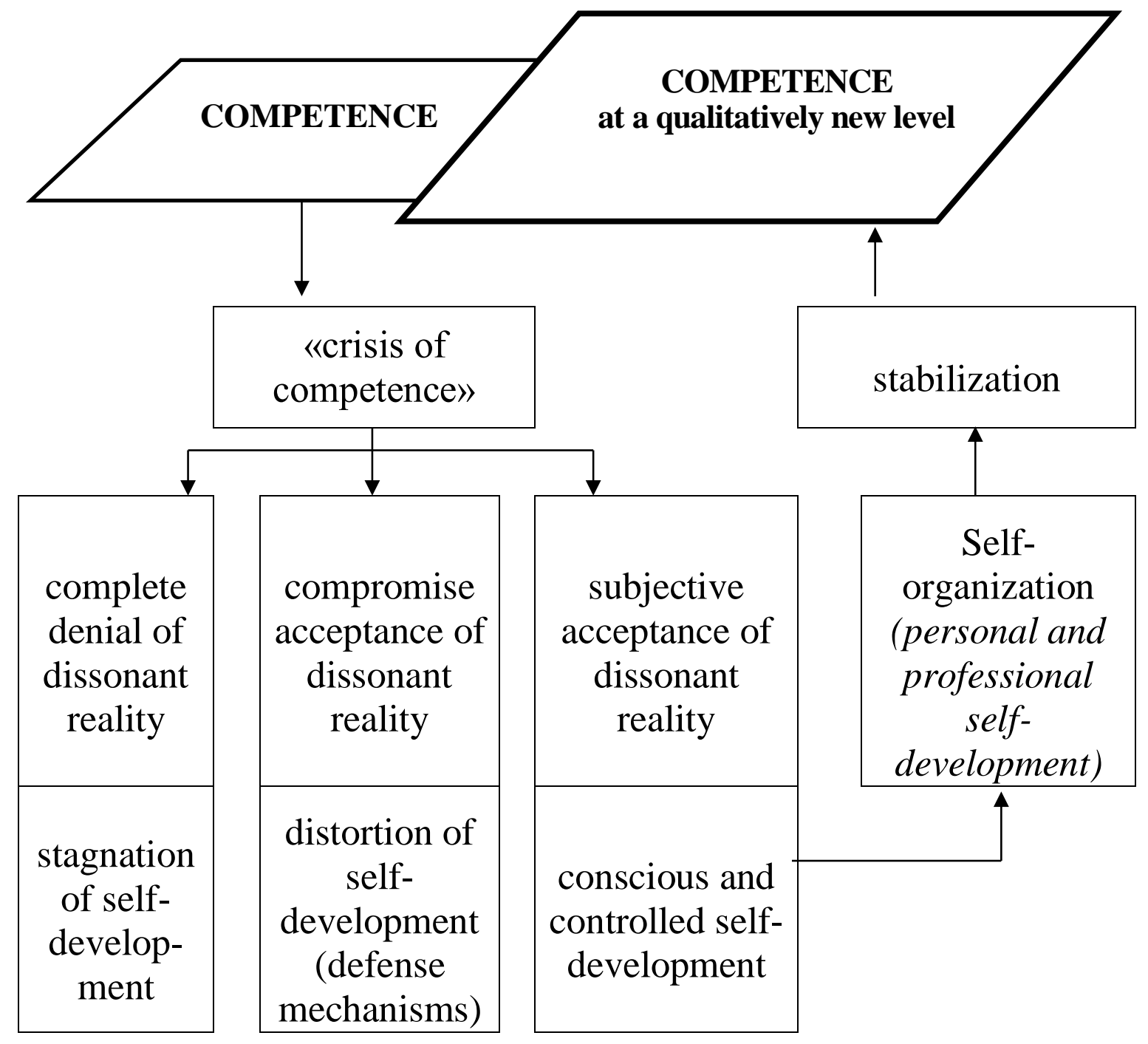

Fig. 2. Model of a professional personal's self-development. Dynamics of professional competence

However, in this case, a person is evaluated as a function, a notional person, an artifact. It does not take into account that the peak of selfdevelopment of the individual does not necessarily coincide with the peak of his expression as a subject of professional activity. In the life of each person there are the peaks of professional self-development and 
fall, often associated with the narrowing and impoverishment of its relationship with reality. Such an involution of self-development of a person can lead to its deformation and degradation. However, permanent awareness of oneself in professional activities, distancing from professional problems, their analysis and change in content, tactics, relationships, attitudes, etc., that is, the constant implementation of professional and personal self-development, will allow a specialist to maintain his professional and psychological health, prevent professional and personal burnout.

Considering the indicated unevenness of the dynamics of competence development, it is possible to predict several ways of professional formation of a specialist. If at the stage of "competence" a specialist, with one degree or another of freedom perceives himself as competent, then a dissonant collision with new situations and circumstances of professional activity can lead to a crisis of competence. Stage of "crisis of competence" confronts specialist with a choice: complete denial of dissonant reality, compromise acceptance of dissonant reality (often unconscious, based on the principles of psychological defense mechanisms), acceptance of dissonant reality, and reorganization of the previous model of behavior (realized on the principle of psychological distancing). Finding by a specialist a new knowledge and methods of activity, introspection, self-determination, self-organization, self-regulation will ensure a gradual restoration of lost competence at a qualitatively new level at the stage of "selforganization". This will allow a specialist to enter a new stage of professional growth and find a sense of competence in the process of solving various by nature and the complexity of tasks problems at the stage of "stabilization". Consequently, the growth of professional competence depends directly on the ability of a person to assume responsibility in the situation of choice. For this purpose a meaningful attitude of the subject of activity to himself, as well as continuous personal and professional self-development, is necessary. According to our position indicated process of personality changes (the process of reflexive self-regulation of the individual) determines the psychological culture of a specialist.

Consider another important point. Social relations, interpersonal relationships, and the person are not something steady. The dynamism of life leads to its rethinking and requires constant changes and constant 
work on oneself, including finding the meanings of existence, professional activities and means of realization, which will also help to avoid professional and personal burnout. The value-semantic aspect of the specialist's subjective behavior in the context of self-development concept is given in the model (conceptual scheme) of professional selfdevelopment of individual (Fig. 3).

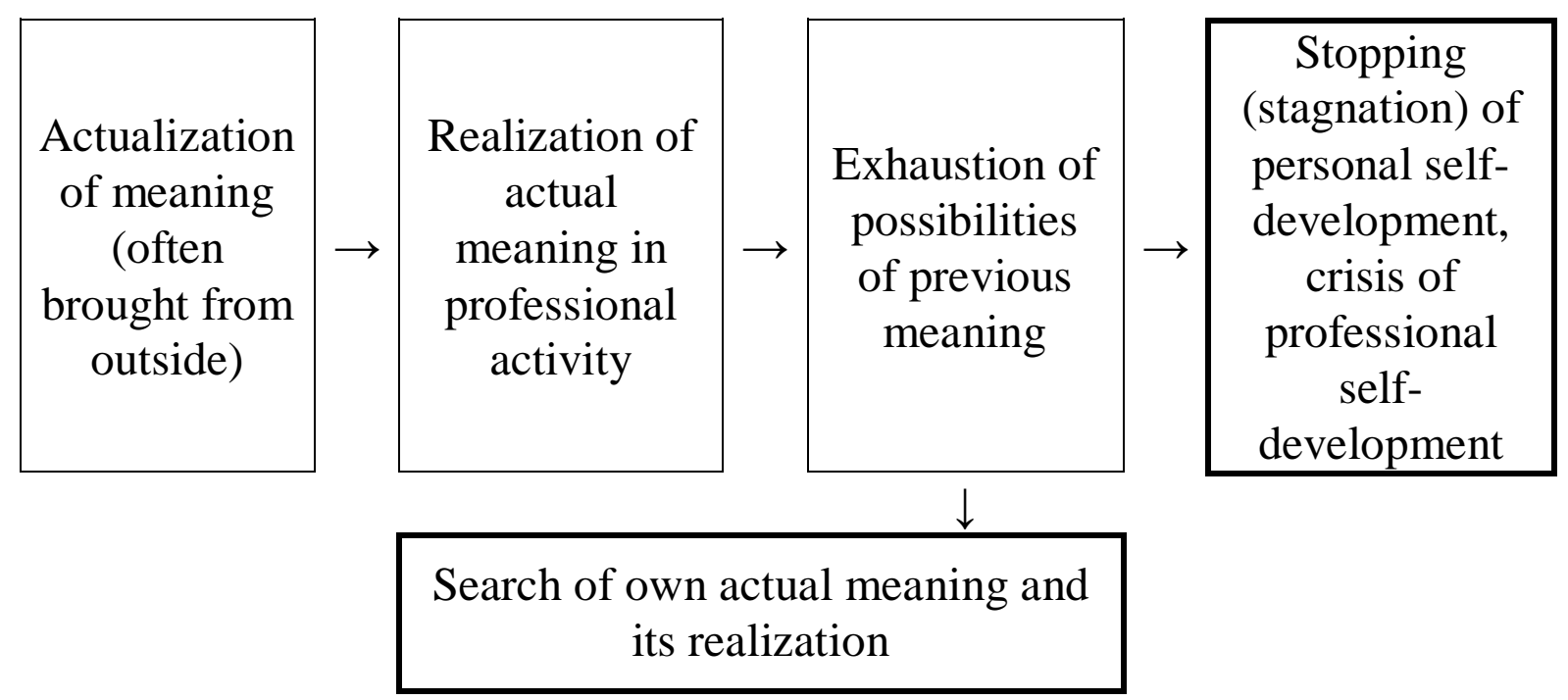

Fig. 3. Model of professional self-development of personality. Dynamics of personal meanings of professional activity

People continue to develop their semantic systems throughout their lives. The acquisition of new life and social roles makes a person look at a lot of things in a new way. A person in development continuously allocates itself from the general community and at the same time understands self integration with the wider world. This process becomes possible due to the fact that at each stage of development, the old becomes a part of a new (cyclic development). At the same time valuesemantic system forms the human experience, organizes individual cognitive and emotional spheres, directs the behavior and serves a source of development.

Let's emphasize that the formed system of personal meanings becomes the regulator of personal development, since the realization of life experience has a focus on already perceived, internalized life goals, which acquire meaningful life perspectives.

Absence of life meaning and the impossibility (or inability) to find it entails person transition to a lower level of self-organization, and it can cause degradation of the individual. 
Formation of the indicated criteria (model parameters) of a professional specialist, namely, awareness of oneself in the profession and continuous personal and professional self-development, are of particular importance when organizing the professional training of students-future psychologists. Primarily this is predetermined by specifics of the professional activity of a practical psychologist - its focus on providing psychological care to others. In the process of activity, the psychologist has to work with different age, social, and cultural categories of people, but the object of his activity is always the individuality of a person who appealed for help to a specialist as a person competent in life's difficulties and problems. It should be taking into account that in the process of such interaction, the psychologist becomes an element of the close environment of this person. All this demands from the psychologist special individual qualities, a broad, optimistic worldview, a progressive system of values and, particularly, a meaningful, internationalized attitude towards himself as a subject of professional activity, his own life and selfdevelopment. These characteristics determine the professional culture of a specialist psychologist.

In the focus of our scientific and applied interests is the development of a system of training students-practical psychologists for the implementation of psycho-corrective activities. The author's research is based on the conceptual foundations of the study of psychologist's personality, in general, and at the stage of professional training in the system of higher education, in particular (O. Bondarenko, J. Virna, L. Dolinskaya, L. Mitina, E. Nosenko, V. Panok, N. Poviakel, N. Shevchenko).

The analysis of the works of these scholars convincingly shows that the process of preparing future specialists in the field of practical psychology should include not only the mastering of theoretical knowledge (which, in general, is sufficient for the training of teachers on the subject), but also the formation of professionally important features of specialist's personality. It can be said in this case that the focal point of practical psychologists' training should be personal training of future specialists, which integrates all other elements of this system (theoretical and practical components).

O. Bondarenko considers that the lack of elaboration of personal problems (frustrated or unrealistic needs, fantasies, fears, conflicts, defenses, value meanings, self-esteem, motives, etc.) and lack of 
professional (practical and theoretical) training can easily, instead of psychological help, injure as client as specialist, adding psychogenic disorders to unresolved problems 9 .

An important indicator of a professional level (professional competence) and personal readiness of a psychologist-practitioner to provide psychological care to others is the need and the ability do not get around himself but from client and his problem that is, a certain personal decentralization. For that it is necessary in the process of students' preparing for professional activities in providing psychological assistance to clients, firstly, to solve personal problems of the future specialist, which increases subjectivity and bias in the assessment of the client's personality and problems. Secondly, the formation of a new attitude towards oneself and other people is necessary, as well as a new vision of problems, a new type of thinking - flexible, not fixed on any norms, standards, broader, optimistic, centered on the client. This aspect of professional training is impossible without experience of personal change, personal growth.

It follows that the process of preparing students-psychologists for professional, first of all, psycho-correctional activity, should include some individual work with each of them. Namely it is an identification of personal problems of students at the beginning of studies (questionnaires, projective tests, drawings, verbal associations, etc.) and constant interaction with them in order to solve these problems, as long as they exist, through psychological counseling, teaching methods of self-examination, self-regulation, self-correction and finally continuous work on a self under the direction of a teacher-psychologist, a specialist in the field of psycho-correction or psychological counseling.

\section{CONCLUSIONS}

Let's conclude. According to our position, psychological culture as a personal property reflects subject's attitude to restrictions and resources of personal growth; it is characterized by the efficiency and ecology of developed personal psychological techniques (individuallyspecific psychological means of management of psyche and behavior) of restructuring of subjective life experience. The last statement

${ }^{9}$ Бондаренко А.Ф. Психологическая помощь : теория и практика. Київ : Освіта України, 2007. 332 с. 
emphasizes significance of psychological work on creating a youth value orientation towards self-development, the attitude towards oneself as a subject of their own changes, and also providing it with means of selfdevelopment.

According to our concept ability to be a subject of personal and professional self-development should be a leading and generalizing criterion, which defines a professional, in general, and in the field of providing psychological assistance, in particular. Such professionally significant personal qualities as the ability to make meaningful choices (self-activity, intentionality) and to be responsible for their own vitality (internality), tolerance to other people and new information, energy, increased vital tone (search activity), ability to find a way out of difficult situations (creative activity), fixation not on problems, but on the possibilities of their solution (positive-effective life setting), selfconfidence and confidence in potential capabilities (integrity and strength of I), which we consider individual stylistic characteristics of self-identity, at the same time determine the professional competence. They allow engaging effectively all the knowledge, skills obtained in an institution of higher education in their practical work at an appropriate level of formation.

We consider it vitally important to form a future psychologistpractitioner a vision of himself as an active figure (creator) of his own changes. Thanks to the experience gained from working on self, this will increase a personal competence, autonomy, tolerance and flexibility in interaction with the client and the world around, in particular. In the context of professional self-development, the transition from object to subjective behavior will increase the efficiency and environmental effectiveness of the future psychologist-practice; it forms a high level of his psychological personal and professional culture.

\section{SUMMARY}

The concept of "psychological culture" of a person, as a result of ideological conceptualization of reality, designed in the form of a semantic picture of the world has been highlighted in the section. The psychological culture has been presented as individual's ability to conscious and controlled self-development. The results of the theoretical and empirical research of the possibilities of managing self-changing and creation of conditions for the formation of the subject of personal 
self-development in adolescence have been analyzed. Correlation between personal and professional self-development of a specialist has been revealed. Its success criteria have been substantiated. Continuous personal and professional self-development has been defined as an indicator of individual professional culture. The directions of youth psychological culture formation, such as strengthening of subject's activity and experience of self-development, have been outlined.

\section{REFERENCES}

1. Кузікова С.Б. Психологічні основи становлення суб'єкта саморозвитку в юнацькому віці : монографія. Суми : Видавництво «МакДен, 2012. 410 с.

2. Jung Carl. Synchronicity - An Acausal Connecting Principle. Vol. 8. of the Collected Works of C. G. Jung. 2010, 1972. 147 p.

3. Seligman Martin E. P. Helplessness : On Depression, Development, and Death. San Francisco : W. H. Freeman, 1992. 250 p.

4. Angyal A. Foundations for a science of personality. New York : Commonwealth Fund, 1941. 398 p.

5. Maslow A. Motivation and personality. New York : Harper \& Row; 2nd Edition, 1970. 369 p.

6. Леонтьев Д.А. К дифференциальной антропологии. Наука $u$ будущее : идеи, которье изменят мир : Материалы междунар. конф. Москва, 2004. С. 107.

7. Obuchowski K. Człowiek intencjonalny, czyli o tym jak być sobą. Dom Wydawniczy REMIS, 2000. $257 \mathrm{~s}$.

8. Маркова А.К. Психология профессионализма. Москва, 1996. $308 \mathrm{c}$.

9. Бондаренко А.Ф. Психологическая помощь : теория и практика. Київ : Освіта України, 2007. 332 с.

\section{Information about the authors:} Kuzikova S. B.

Grand $\mathrm{PhD}$ in Psychological Sciences, Professor, Head of the Department of Psychology Sumy State Pedagogical University named after A. S. Makarenko Ministry of Education and Science of Ukraine 87, Romenska str., Sumy, 40000, Ukraine 